\title{
Granulomatous myositis induced by anti-PD-1 monoclonal antibodies
}

Naohiro Uchio, MD, Kenichiro Taira, MD, Chiseko Ikenaga, MD, Atsushi Unuma, MD, Masato Kadoya, MD, Akatsuki Kubota, MD, PhD, Tatsushi Toda, MD, PhD, and Jun Shimizu, MD, PhD

Neurol Neuroimmunol Neuroinflamm 2018;5:e464. doi:10.1212/NXI.0000000000000464

With the expanding use of immune checkpoint blockers typified by anti-programmed death-1 (PD-1) and anti-cytotoxic T-lymphocyte-associated protein 4 monoclonal antibodies (Abs) for antitumor therapy, the number of patients showing immune-related adverse events (irAEs) is increasing. Skeletal muscle is one of the target tissues of irAEs and several features of myopathy as irAEs have been reported: myasthenia gravis (MG) overlap, cardiac involvement, necrotizing myopathy, and inflammatory myopathy with T-cell and B-cell infiltration. ${ }^{1-4}$ However, the immunopathogenesis of muscle destruction remains unclear. Here, we report 2 cases of granulomatous myositis after anti-PD-1 therapy.

\section{Case reports}

\section{Case 1}

A 79-year-old woman with stage IV lung adenocarcinoma developed nonfatigable mild proximal limb weakness (Medical Research Council [MRC] grade 4) 14 days after the fourth cycle of nivolumab. She presented no skin rash and showed no ocular, bulbar, truncal, or respiratory symptoms. She had well-controlled concurrent breast cancer. Laboratory test results showed an elevated serum creatine kinase (CK) level of 1,638 IU/L. Myositis-specific autoantibodies (MSAs), anti-acetylcholine receptor (AChR) Ab, and anti-titin Ab were negative. Antistriated muscle Abs were not measured. Electrocardiography findings were normal. EMG showed spontaneous activity. Chest CT showed no lesions except the cancers.

Biopsy of the biceps brachii muscle showed patchy mononuclear cell infiltrates and granuloma formation in muscle fascicles (figure $1 \mathrm{~A}$ ). In the granulomas, CD11 $\mathrm{c}^{+} \mathrm{M} 1$ and $\mathrm{CD}_{163^{+}} \mathrm{M} 2$ macrophages were abundant (figure e-1, links.lww.com/NXI/A46), and $\mathrm{CD} 11 \mathrm{c}^{+} \mathrm{M} 1$ macrophages frequently invaded non-necrotic fibers and formed granulomatous collection inside the basal lamina of muscle fibers (figure $1, \mathrm{~B}-\mathrm{D}$ ). $\mathrm{CD} 8^{+} \mathrm{T}$ cells invading non-necrotic fibers were also observed (figure $1 \mathrm{E}$ ). PD- $1^{+}$cells were scattered in granulomas (figure $1 \mathrm{~F}$ ), and programmed death-ligand 1 (PD-L1) was upregulated on the non-necrotic fibers around granulomas (figure 1G). Electron microscopy confirmed the macrophage invasion of non-necrotic fibers (figure e-2, links.lww.com/NXI/A46). Nivolumab was discontinued, and oral prednisolone $50 \mathrm{mg}$ was started. Her symptoms improved dramatically with complete resolution, and prednisolone was tapered off within 3 weeks. During 20 months of follow-up, she showed no neurologic recurrence and received conventional chemotherapy.

\section{Case 2}

A 70-year-old man who received pembrolizumab (anti-PD-1 Ab) and axitinib (tyrosine kinase inhibitor) for treatment of renal cell carcinoma developed left ptosis, diplopia, and weakness with myalgia in his neck and left shoulder (MRC grade 4) without bulbar, respiratory, or cardiac

\author{
Correspondence \\ Dr. Shimizu \\ jshimizu-tky@umin.net
}

From the Department of Neurology (N.U., K.T., C.I., A.U., A.K., T.T., J.S.), Graduate School of Medicine, The University of Tokyo, Japan; and Department of Neurology and Anti-aging Medicine (M.K.), National Defense Medical College, Saitama, Japan.

Funding information and disclosures are provided at the end of the article. Full disclosure form information provided by the authors is available with the full text of this article at Neurology.org/NN.

The Article Processing Charge was funded by the authors.

This is an open access article distributed under the terms of the Creative Commons Attribution-NonCommercial-NoDerivatives License 4.0 (CC BY-NC-ND), which permits downloading and sharing the work provided it is properly cited. The work cannot be changed in any way or used commercially without permission from the journal. 

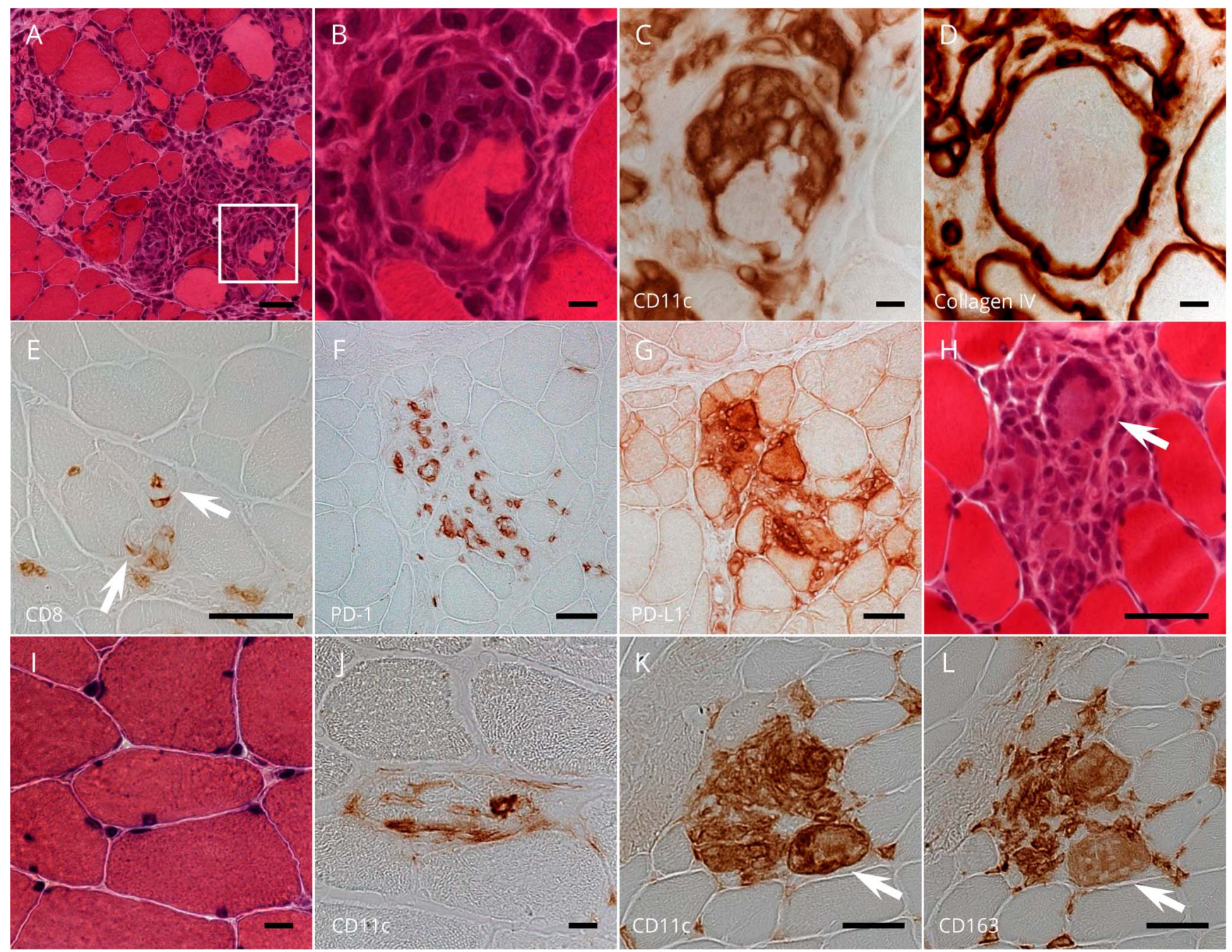

(A-G) Case 1. (A) Hematoxylin and eosin (H\&E) staining showing granulomas in endomysium. (B-D) Serial sections of a high-power view of the square area in (A) with (B) H\&E staining and immunohistochemical analysis of (C) CD11 and (D) collagen IV CD11 $\mathrm{C}^{+}$M1 macrophages invading non-necrotic muscle fibers and forming granulomatous collection inside collagen IV-positive basal lamina. (E) CD8 ${ }^{+}$T cells infiltrating endomysium and invading non-necrotic fiber (arrows). (F) Scattered PD-1 ${ }^{+}$cells in granuloma and (G) PD-L1 overexpression on granuloma cells and non-necrotic fibers surrounding granuloma. (H-L) Case 2. (H) H\&E staining of endomysial granuloma with multinucleated giant cell (arrow). Serial sections with (I) H\&E staining and (J) immunohistochemical analysis of CD11 showing $C D 11 c^{+}$macrophages attacking non-necrotic fiber. Serial sections immunostained for (K) CD11C and (L) CD163 showing macrophages forming granulomatous collection within muscle fibers consisting of CD11 $\mathrm{c}^{+} \mathrm{M} 1$ and $\mathrm{CD} 163^{+} \mathrm{M} 2$ macrophages (arrows). Bars: $50 \mu \mathrm{m} \mathrm{for} \mathrm{A}, \mathrm{E}, \mathrm{F}, \mathrm{G}, \mathrm{H}, \mathrm{K}$, and $\mathrm{L}$, and $10 \mu \mathrm{m}$ for B, C, D, I, and J. PD-1 = programmed death-1; PD-L1 = programmed death-ligand 1.

symptoms 2 days after the second cycle of pembrolizumab. He showed no fluctuation of symptoms or fatigability. Laboratory test results showed an elevated serum CK level of $1,832 \mathrm{IU} / \mathrm{L}$, positivity for anti-AChR $\mathrm{Ab}(0.8 \mathrm{nmol} / \mathrm{L})$, and negativity for MSAs. Anti-striated muscle Abs were not measured. EMG of the right arm and repetitive nerve stimulation (RNS) in the left deltoid muscle showed no abnormalities. Electrocardiography and chest CT findings were normal.

Biopsy of the left deltoid muscle showed mononuclear cell infiltration and giant-cell granulomas (figure $1 \mathrm{H}) . \mathrm{CD} 11 \mathrm{c}^{+}$ M1 macrophages frequently invaded non-necrotic fibers (figure 1, I and J). Small granulomas replacing muscle fibers always contained both $\mathrm{CD} 11 \mathrm{c}^{+} \mathrm{M} 1$ and $\mathrm{CD}_{163^{+}} \mathrm{M} 2$ macrophages (figure $1, \mathrm{~K}$ and $\mathrm{L}$ ). Pembrolizumab was discontinued and IV immunoglobulin, oral prednisolone $30 \mathrm{mg}$, and pyridostigmine were started. His symptoms improved markedly with normalization of serum CK within 1 month. Prednisolone was tapered to $7.5 \mathrm{mg}$ over the next 5 months. During 6 months of follow-up, he showed no neurologic or oncological recurrence.

\section{Discussion}

In this study, we reported cases of granulomatous myositis as an irAE. Although patients with necrotizing myopathy with a fatal outcome were reported previously, ${ }^{2}$ our 2 patients showed a favorable outcome of immunosuppressive therapy. 
One patient (case 2) with low-titer anti-AChR Ab may be overlapped with MG. Low titers of anti-AChR Ab with normal RNS were reported in patients with MG or myopathy-MG overlap as irAEs. ${ }^{2,4}$

The pathomechanisms of myopathy as an irAE are still unclear. Activated $T$ cells, which target an antigen shared by tumors and skeletal muscles, have been suggested to have a role in irAEs. ${ }^{1}$ Our study showed not only $\mathrm{T}$ cells attacking non-necrotic fibers but also M1 macrophages attacking non-necrotic fibers and forming granulomas, indicating that macrophages along with $\mathrm{T}$ cells are involved in the immunopathogenesis. Both proinflammatory M1 and anti-inflammatory M2 macrophages are involved in granuloma formation. ${ }^{5}$ Recent studies suggest that PD-1 inhibition directly affects macrophages and PD-1 depletion induces M1 polarization. ${ }^{6,7}$ In our cases, PD-1 blockade may have promoted M1 polarization, leading to the M1 macrophage invasion of non-necrotic fibers with granuloma formation.

Of interest, PD-L1 was overexpressed on non-necrotic fibers around granulomas. $\mathrm{PD}-1 / \mathrm{PD}-\mathrm{L} 1$ pathway activation inhibits immune-mediated attacks by $\mathrm{T}$ cells. Therefore, PD-L1 upregulation on non-necrotic fibers may be a protective reaction. To explore measures to prevent myopathy as an irAE, further studies on the immunopathogenesis are necessary.

\section{Author contributions}

Dr. Uchio: study design and concept, acquisition of data, analysis and interpretation, and drafting of the manuscript. Drs. Taira, Ikenaga, Unuma, and Kadoya: acquisition of data. Dr. Kubota: critical revision of the manuscript. Dr. Toda: study supervision. Dr. Shimizu: study design and concept, acquisition of data, analysis and interpretation, and critical revision of the manuscript.

\section{Acknowledgment}

The authors thank Drs. Ryo Usui, Keiichi Hokkoku (Teikyo University School of Medicine), Tatsuhiko Naito, Masao Osaki, and Yoshikazu Uesaka (Toranomon Hospital) for help in the acquisition of clinical data of the patients.

\section{Study funding}

No targeted funding reported.

\section{Disclosure}

N. Uchio, K. Taira, C. Ikenaga, A. Unuma, M. Kadoya, A. Kubota, and T. Toda report no disclosures. J. Shimizu is supported by a Health and Labour Sciences Research Grant on Rare and Intractable Diseases (Validation of Evidencebased Diagnosis and Guidelines, and Impact on QOL in Patients with Neuroimmunological Diseases) from the Ministry of Health, Labour and Welfare of Japan and a Grant-inAid for Scientific Research (KAKENHI; 15K09347) from JSPS. Full disclosure form information provided by the authors is available with the full text of this article at Neurology.org/NN.

Received January 26, 2018. Accepted in final form March 29, 2018.

\section{References}

1. Johnson DB, Balko JM, Compton ML, et al. Fulminant myocarditis with combination immune checkpoint blockade. N Engl J Med 2016;375:1749-1755.

2. Liewluck T, Kao JC, Mauermann ML. PD-1 inhibitor-associated myopathies: emerging immune-mediated myopathies. J Immunother 2018;41:208-211.

3. Gandiga PC, Wang AR, Gonzalez-Rivera T, Sreih AG. Pembrolizumab-associated inflammatory myopathy. Rheumatology (Oxford) 2018;57:397-398.

4. Suzuki S, Ishikawa N, Konoeda F, et al. Nivolumab-related myasthenia gravis with myositis and myocarditis in Japan. Neurology 2017;89:1-8.

5. Hilhorst M, Shirai T, Berry G, Goronzy JJ, Weyand CM. T cell-macrophage interactions and granuloma formation in vasculitis. Front Immunol 2014;5:1-14.

6. Gordon SR, Maute RL, Ben W, et al. PD-1 expression by tumour-associated macrophages inhibits phagocytosis and tumour immunity. Nature 2017;545:495-499.

7. Chen W, Wang J, Jia L, Liu J, Tian Y. Attenuation of the programmed cell death-1 pathway increases the M1 polarization of macrophages induced by zymosan. Cell Death Dis 2016;7:e2115. 


\title{
Neurology \\ Neuroimmunology \& Neuroinflammation
}

\author{
Granulomatous myositis induced by anti-PD-1 monoclonal antibodies \\ Naohiro Uchio, Kenichiro Taira, Chiseko Ikenaga, et al. \\ Neurol Neuroimmunol Neuroinflamm 2018;5; \\ DOI 10.1212/NXI.0000000000000464
}

This information is current as of April 27, 2018

\section{Updated Information \& Services}

References

Subspecialty Collections

Permissions \& Licensing

Reprints including high resolution figures, can be found at:

http://nn.neurology.org/content/5/4/e464.full.html

This article cites 7 articles, 0 of which you can access for free at: http://nn.neurology.org/content/5/4/e464.full.html\#\#ref-list-1

This article, along with others on similar topics, appears in the following collection(s):

Muscle disease

http://nn.neurology.org//cgi/collection/muscle_disease

Information about reproducing this article in parts (figures,tables) or in its entirety can be found online at:

http://nn.neurology.org/misc/about.xhtml\#permissions

Information about ordering reprints can be found online: http://nn.neurology.org/misc/addir.xhtml\#reprintsus

Neurol Neuroimmunol Neuroinflamm is an official journal of the American Academy of Neurology.

Published since April 2014, it is an open-access, online-only, continuous publication journal. Copyright

Copyright (C) 2018 The Author(s). Published by Wolters Kluwer Health, Inc. on behalf of the American

Academy of Neurology.. All rights reserved. Online ISSN: 2332-7812.

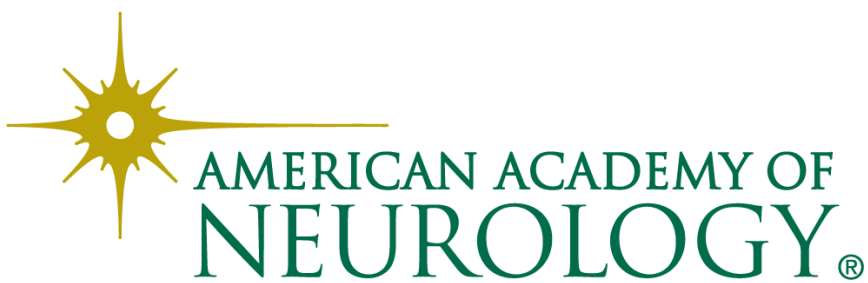

